\section{Planting Date and Cultivar Affect Melon Quality and Productivity}

\author{
Robert J. Dufault ${ }^{1}$, Ahmet Korkmaz ${ }^{2}$, Brian K. Ward, and \\ Richard L. Hassell \\ Coastal Research and Education Center, Department of Horticulture, \\ Clemson University, 2700 Savannah Highway, Charleston, SC 29414
}

Additional index words. Cucumis melo, cantaloupe, honeydew, cold tolerance, phenology, stress, cucurbitaceae

\begin{abstract}
Extending the production season of melons (Cucumis melo L.) by using very early and late planting dates outside the range that is commercially recommended will increase the likelihood of developing a stronger melon industry in South Carolina. The objective of this study was to determine if early (February) transplanted melons or later (June through July) planting dates are effective in extending the production season of acceptable yields with good internal quality of the melon cultivars: Athena, Eclipse, and Sugar Bowl and Tesoro Dulce (a honeydew melon). Melons were transplanted in Charleston, S.C., in 1998, 1999, and 2000 on 12 and 26 Feb., 12 and 26 Mar., 9 and 23 Apr., 7 and 21 May, 4 and 18 June, and 2 July and required 130, 113, 105, 88, 79, 70, 64, 60, 60, 59, and 56 days from field transplanting to reach mean melon harvest date, respectively. Stands were reduced $67 \%, 41 \%$, and $22 \%$ in the 12 and 26 Feb. and 12 Mar. planting dates, respectively, in contrast to the 26 Mar. planting date but $\leq 15 \%$ in all other planting dates. Planting in February had no earliness advantage because the 12 and $26 \mathrm{Feb}$. and 12 and 26 Mar. planting dates, all reached mean melon harvest from 19 to 23 June. Comparing the marketable number of melons produced per plot (averaged over cultivar) of the standard planting dates of 12 and 26 Mar. indicated decreases of $21 \%$, $32 \%, 36 \%, 36 \%, 57 \%, 57 \%$, and $54 \%$, respectively with the planting dates of 9 and 23 Apr., 7 and 21 May, 4 and 18 June, and 2 July. The most productive cultivar of all was 'Eclipse', which yielded significantly more melons per plot in all 11 planting dates followed by 'Athena' (in 8 of 11 planting dates), 'Tesoro Dulce' ( 7 of 11 planting dates), and 'Sugar Bowl' ( 2 of 11 planting dates). In our study, any planting date with melon quality less than the USDA standard of "good internal quality" or better (Brix $\geq 9.0$ ) was considered unacceptable because of potential market rejection. Therefore, the earliest recommended planting date with acceptable yield and "good internal quality" was 12 Mar. for all cultivars; the latest planting dates for 'Athena', 'Eclipse', 'Tesoro Dulce', and 'Sugar Bowl' were 4 June, 18 June, 7 May, and 9 Apr., respectively. With these recommendations, the harvest season of melons lasted 40 days from 24 June to 3 Aug. for these four cultivars, which extended the production season an additional 2 weeks longer than the harvest date of last recommended 21 May planting date.
\end{abstract}

Current commercial melon production recommendations in coastal South Carolina suggest that the earliest and latest recommended planting dates are about 15 Mar. and 15 May, respectively (Sanders, 2005). To establish the earliest market possible, many growers transplant earlier than recommended planting date and risk freeze injury to newly transplanted melons. Extending the production season would also be desirable to maintain dominance in the market; however, late planting dates are difficult because of the increased intensity of insect and disease pressure into the summer. To extend the production of melons much longer, growers need to make earlier than and alter recom-

\footnotetext{
Received for publication 24 Apr. 2006. Accepted for publication 17 Aug. 2006.

${ }^{1}$ To whom reprint requests should be addressed; e-mail bdflt@clemson.edu.

${ }^{2}$ Current address: Kahramanmaras University, Faculty of Agriculture, Department of Horticulture, Kahramanmaras, Turkey 46060.
}

mended plantings and select cultivars that excel in those growing seasons. A major problem for using these nontraditional planting dates is the lack of knowledge of how different cultivars will react to the unique conditions of temperature, daylength, rainfall, humidity, and so on, relative to yield, quality, and disease.

Changes in melon quality are the result of complex genetic, physiological, and environmental influences. From the consumer's standpoint, quality melons must be sweet, flavorful, and reasonably firm. Various studies have been published in diverse locations evaluating the performance of various melons planted on multiple planting dates in Korea (Lee et al., 1998), Jamaica (McGlashan and Fielding, 1990), Texas (Bruton et al., 1985), and India (Nandpuri and Lai, 1978). The conclusions reached are specific to those regions because of genotype/environment interactions that modify plant growth specific to unique climatic conditions. Differences in diurnal temperature or light levels (i.e., daylength, solar radiation), soil types, and a milieu of other microclimatic conditions make extrapolation of others' results to our region difficult. For planting date/cultivar selection for commercial production to be successful in any locality, research needs to be done near potential production sites. The objective of this study was to determine if transplanting melons earlier than recommended mid-March planting dates or later than the last recommended 15 May planting date were effective in extending the production season of Athena, Eclipse, and Sugar Bowl and Tesoro Dulce (a honeydew melon cultivar) based on yields and internal qualities.

\section{Materials and Methods}

Eleven planting dates were evaluated (12 and 26 Feb., 12 and 26 Mar., 9 and 23 Apr., 7 and 21 May, 4 and 18 June, and 2 July) from 1998 to 2000 resulting in 32 different environments. These planting dates were selected to establish the earliest and latest possible planting dates for continuous summer production of melons in the coastal area of South Carolina.

Melon transplants were hand-planted on each planting date at the two-true-leaf stage. Raised beds on 1.8-m centers were fumigated with methyl bromide and broadcast fertilized with $120 \mathrm{~N}-53 \mathrm{P}-104 \mathrm{~K} \mathrm{~kg} \cdot \mathrm{ha}^{-1}$ and then the beds were covered with black plastic mulch. Each plot was $3.7 \mathrm{~m}$ long and contained 12 plants. The plots were replicated four times and arranged in a Latin Square design with each cultivar represented in each row and column. The soil was Yauhannah loamy fine sand (Aquic Hapludults). Commercial pest management and similar cultural practices were used for all planting dates (Sanders, 2005). The herbicide, ethalfluralin (a.i.) at 1.9 $\mathrm{kg} \cdot \mathrm{ha}^{-1}$, was applied to the soil between mulched beds

Air temperatures were continuously monitored during the 3-year period using a Campbell Scientific Weather Station (Campbell Inc., Logan, Utah). Data were recorded every $15 \mathrm{~min}$, averaged hourly and then daily from the date of transplanting to the last harvest day. The mean growing season temperature was calculated by taking the daily mean and maximum temperatures from each day from transplanting to last harvest and averaging to derive this overall mean growing season temperature for each year.

Plant stand within all plots was recorded just before the vines ran into the wheel rows between mulched beds. Overhead irrigation was applied as necessary per tensiometer readings to supplement rainfall. Ten harvests were made for each planting date. 'Athena', 'Eclipse', and 'Sugar Bowl' melons were harvested at $\geq 3 / 4$ full slip. 'Tesoro Dulce', a nonslipping honeydew type, was harvested when the skin turned a golden color. Individual melons were weighed and the first 10 melons harvested per plot were tested for Brix with a handheld refractometer. All melons were graded for marketability according to U.S. Department of Agriculture (USDA) standards for honeydew (USDA, 1967) and muskmelon 
(USDA, 1968) and melons $<0.6 \mathrm{~kg}$ were "cull." The "internal quality" of melons is defined as the "combined juice from the edible portion of a sample...contains not less than a certain percent soluble solids determined by a hand refractometer." "Very good internal quality" melons have $\geq 11 \%$ soluble solids, whereas "good internal quality" melons have $>9 \%$ to $<11 \%$ soluble solids (USDA, 1968). In our study, melons with $\geq 8 \%$ but $<9 \%$ soluble solids were defined as "acceptable, having fair internal quality." Melons with $<8 \%$ soluble solids were classified as "unacceptable" and cull. Because the USDA standard for honeydews does not mention "internal quality" and soluble solids (USDA, 1967), we used the muskmelon standards for the honeydew cultivar included in the study. Because internal quality is critically important for consumer acceptance, these designations were adhered to determine superiority of a particular planting date. If the average quality of a cultivar within a planting date was less than the "good internal quality" category, the planting date was not recommended even with acceptable yields.

Data were analyzed using PROC GLM procedure of PC SAS (SAS Institute, Cary, N.C.) to determine the effects of planting date, cultivar, and year and the interactions among these factors. If the $\mathrm{F}$ test was significant at $P=0.05$, the means were separated by LSD at $P=0.05$. The relative importance of the planting date, cultivar, and year factors were determined by partitioning of the total sum of squares in the analysis of variance into main and interaction effects and expressing these individual contributions to variation as a percentage of the total sum of squares for the model. The value of these percentages is that they become very useful indicators to compare which factors contributed most to growth, quality, and yield variables relative to the other factors.

\section{Results}

Harvest maturity. The warmest mean monthly temperatures were in all 1998 planting dates and coldest temperatures were in 1999 (Fig. 1). The difference in growing season mean temperatures among the years was significant and affected most of the variables. To make recommendations for

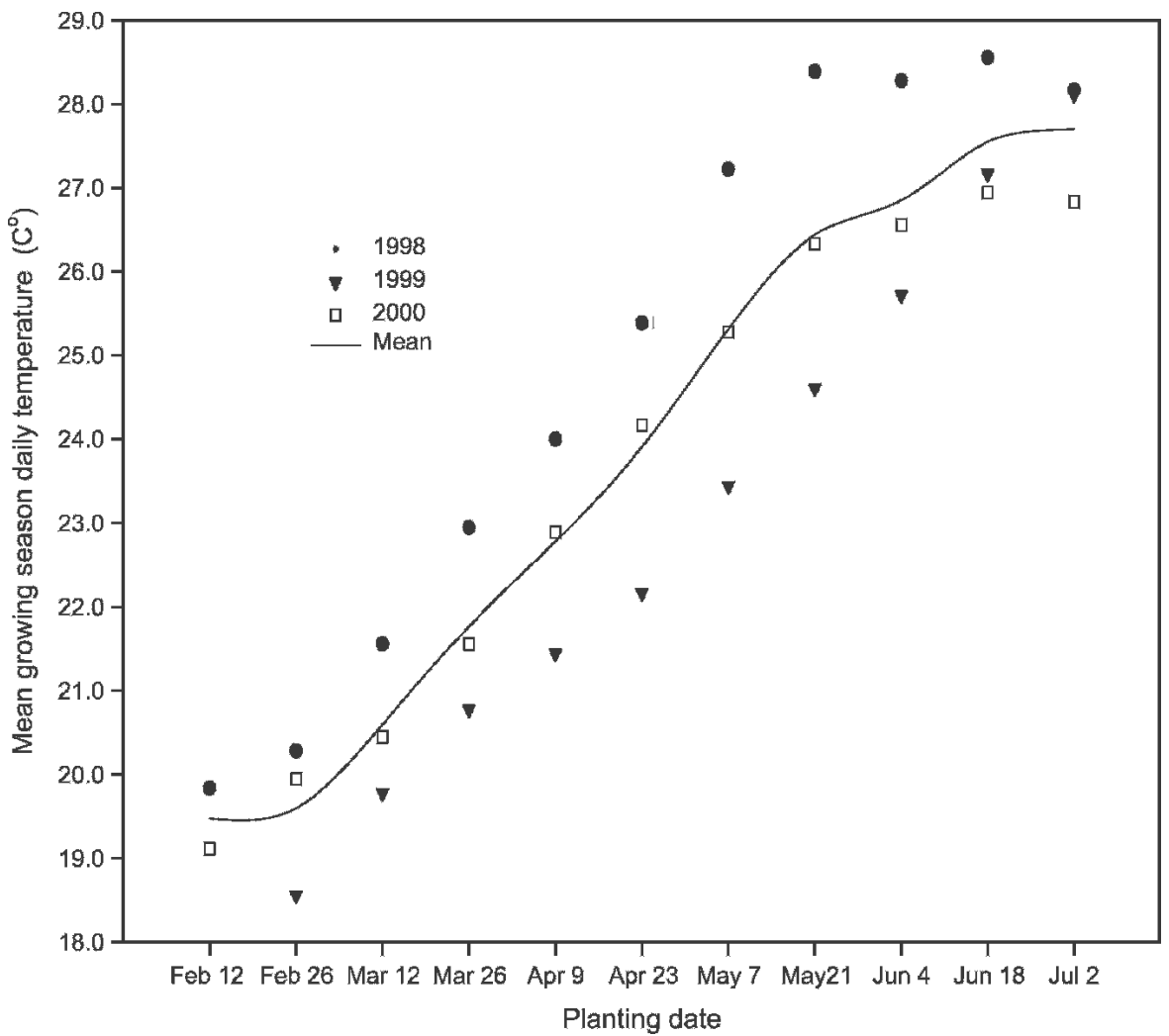

Fig. 1. Mean monthly growing season temperatures from Feb. 1998 to July 2000 were calculated by taking the daily mean maximum and minimum temperatures from field transplanting seedlings to melon harvest.

commercial application, however, the mean response of a planting date needs to be evaluated, but outstanding differences resulting from variation in yearly temperatures is discussed where appropriate. The variation in growing season temperatures among the planting dates greatly affected maturity with $96 \%$ of all partitioned variation in days to mean melon harvest assigned to the main effects of planting date (Table 1). Melons planted on the first planting date of $12 \mathrm{Feb}$. required $\approx 130 \mathrm{~d}$ to mean melon harvest, but significantly less time was needed to reach mean harvest with later planting dates (Fig. 2A). Planting before the recommended midMarch planting date did not produce earlier melons because plantings made on 12 and 26 Feb. and 12 and 26 Mar. all reached mean harvest between 19 and 23 June. The difference in mean growing season temperatures for these first four planting dates was $\approx 3.3{ }^{\circ} \mathrm{C}$ and ranged from 19.5 to $21.8^{\circ} \mathrm{C}$.

Our goal was to produce melons over an extended period, but the actual length of time from first to last harvests of the 11 planting dates used was only $75 \mathrm{~d}$. The harvest dates of earlier planting dates tended to stack up close together, but the later planting dates were more widely spread. The mean harvest of the first five planting dates (12 Feb. to 9 Apr.) occurred from 19 to 27 June, but there were 9-, 11-, 13-, 13-, and 11-d differences, respectively, in mean harvest between the planting dates of 23 Apr. to 7 May, 7 to 21 May, 21 May to 4 June, 4 to 18 June, and 18 June to 2 July. Although planting date

Table 1. Percentages of treatment sum of squares of the model partitioned into main and interaction effects for melon yield variables in response to planting dates, cultivars, and year of planting.

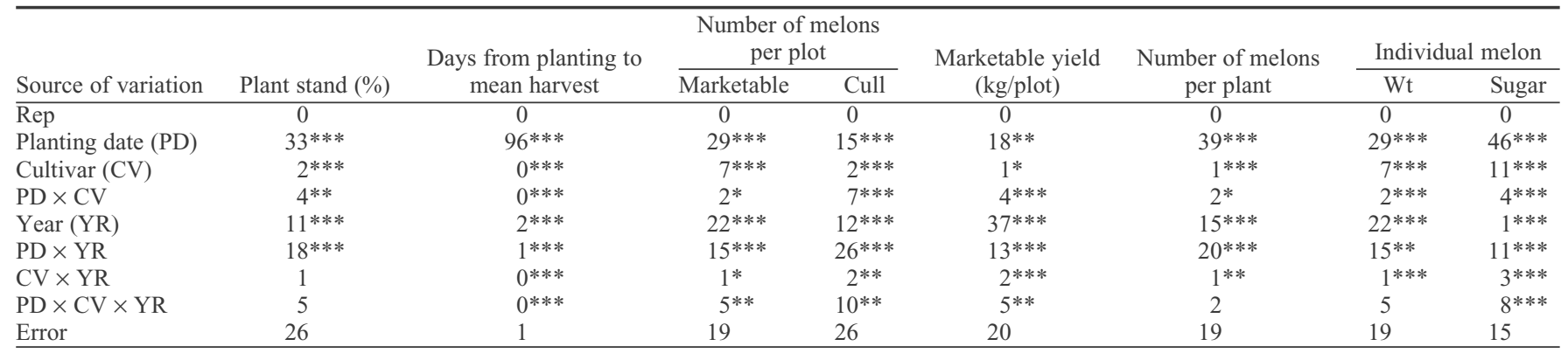

$*, * *, * * * \mathrm{~F}$ test significant at $P=0.05,0.01$, and 0.001 level, respectively. 

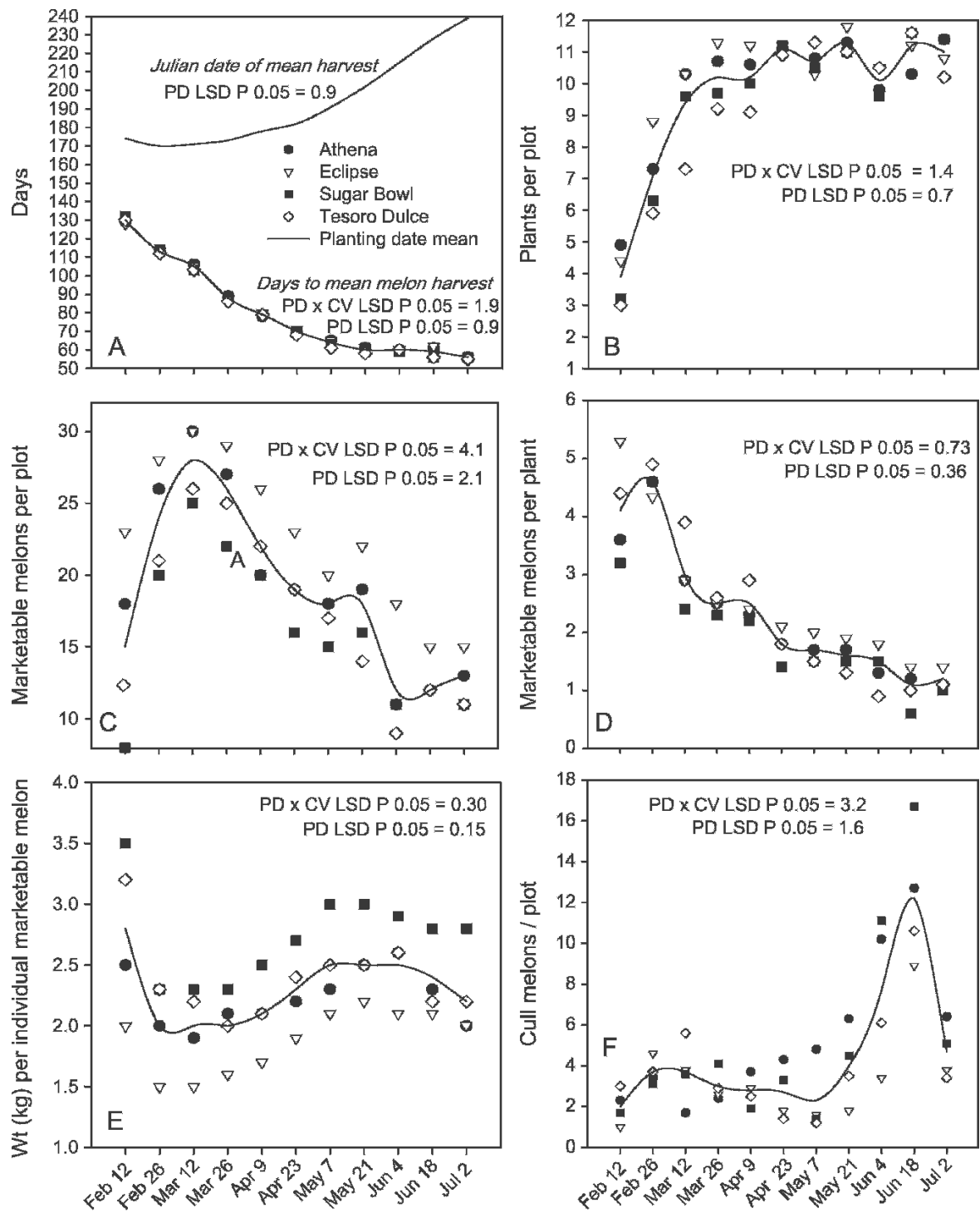

Planting Date

Fig. 2. Influence of planting date from February to July and cultivar on: (A) date of mean harvest and days to mean melon harvest; (B) plants per plot; (C) marketable melons per plot; (D) marketable melons per plant; (E) individual melon weight; and (F) marketable weight per plot of melons grown from 1998 to 2000 in Charleston, S.C.

interacted with cultivar for mean harvest, the differences among cultivars were small.

Plant stand and individual plant yield. The earliest planting dates negatively affected plant stand. The majority of variation in plant stand was partitioned among the main effects of planting date $(33 \%)$ and year $(11 \%)$ and the interaction of planting date and year $(18 \%)$ (Table 1). Stands decreased by $67 \%, 41 \%$, and $22 \%$ in the 12 and $26 \mathrm{Feb}$. and 12 Mar. planting dates, respectively, as a result of cold injury (Fig. 2B). As temperatures increased, stand losses decreased to $\leq 15 \%$ in all planting dates $\geq 26 \mathrm{Mar}$. Cultivars showed variability in cold tolerance with 'Sugar Bowl' and 'Tesoro Dulce' experiencing greater stand losses than 'Eclipse' and 'Athena' in the 12 and 26 Feb. planting dates.

As plant death increased in the earliest planting dates, competition among surviving plants decreased, which allowed more melons to be set per plant. Thirty-nine percent and $29 \%$ of the total variation in the number of melons per plant and individual melon weight, respectively, were attributable to the main effects of planting date with the year main effects contributing $15 \%$ and $22 \%$ to these variables (Table 1). Although individual plants set more fruit per plant in the first three planting dates (based on cultivar means), from 9 Apr. and later, the individual plants produced fewer melons (Fig. 2D). Plants in the 12 and 26 Feb. planting dates produced over four melons per plant, decreasing to $\approx 3$ melons per plant in March planting dates and then $\leq 2$ melons per plant from planting dates $\geq 23$ Apr. Planting date interacted with cultivar and in the first planting date, with 'Eclipse' producing over five melons per plant compared with four for 'Tesoro Dulce' and three for 'Athena' and 'Sugar Bowl'. In later planting dates, however, all the cultivars produced from one to two melons per plant.
Although fewer melons per plant were produced in the later planting dates, the individual melon weight increased up to the 7 May planting date, then plateaued until the 4 June planting date, but decreased with planting dates $\geq 18$ June. Melon weight was heaviest in the first planting date because poor stand greatly reduced plant competition, which promoted greater melon growth (Fig. 2E). In the first planting date of 12 Feb., 'Sugar Bowl' melons weighed $3.5 \mathrm{~kg}$ each, 'Tesoro Dulce' melons weighed $\approx 3.1 \mathrm{~kg}$ each, and 'Athena' and 'Eclipse' weighed even less. From 7 May to 4 June planting dates, melon weight plateaued at $2.5 \mathrm{~kg}$ each, but from the 18 June to 2 July planting dates, the weight decreased and was similar to 26 Mar. planting date melon weight. Pooling melon weight data for all planting dates indicated that 'Sugar Bowl' melons were the heaviest of all cultivars followed by 'Tesoro Dulce', 'Athena', and 'Eclipse'.

Melon yield per plot. The majority of variation in marketable number per plot was attributed to the main effects of planting date $(29 \%)$ and year $(22 \%)$ and the interaction between planting date and year (15\%) (Table 1). Melon yields per plot for each cultivar were greatest in 2000 and lowest in 1998 (Fig. 3). Of the 11 planting dates, yield of melons per plot (pooled over cultivar) were greatest in the 12 and 26 Mar. planting dates but $46 \%$ lower in the 12 Feb. planting date compared with the 12 Mar. planting date (Fig. 2C). There was no yield advantage in earliness or greater yields for planting earlier on either 12 Feb. or 26 Feb. in contrast to the recommended March planting dates. Comparison of yield in all planting dates after 12 Mar. indicated that marketable numbers per plot decreased by $7 \%, 21 \%, 32 \%, 36 \%, 36 \%$, $57 \%, 57 \%$, and $54 \%$, respectively, in the 26 Mar., 9 and 23 Apr., 7 and 21 May, 4 and 18 June, and 2 July planting dates.

Although yield differed yearly, the reduction in yield with planting dates later than 12 Mar. is consistent over the years. To illustrate this best, regression analyses was conducted after discarding the ineffectual February planting dates to determine the best prediction model for each cultivar in relation to the planting date $\times$ year interaction. Polynomial regression indicated that a linear model best described the relationship between yield and planting date by year. As planting date occurred later in time, yield decreased linearly in all contrasts, except in 1998 for 'Eclipse', 'Sugar Bowl', and 'Tesoro Dulce', and were strongest in 2000 (Fig. 3). For the purposes of commercial recommendation, the pooled response overall 3 years with their climatic variation provided a general prediction of the superiority of the planting dates.

Individual melon weight varied over the years and were similar in 1998 and 2000 but lower in 1999 (data not shown). Marketable melon weight per plot did not correlate with the marketable melon number per plot because individual melon weight varied by planting date. Of all 11 planting dates, 'Athena' 


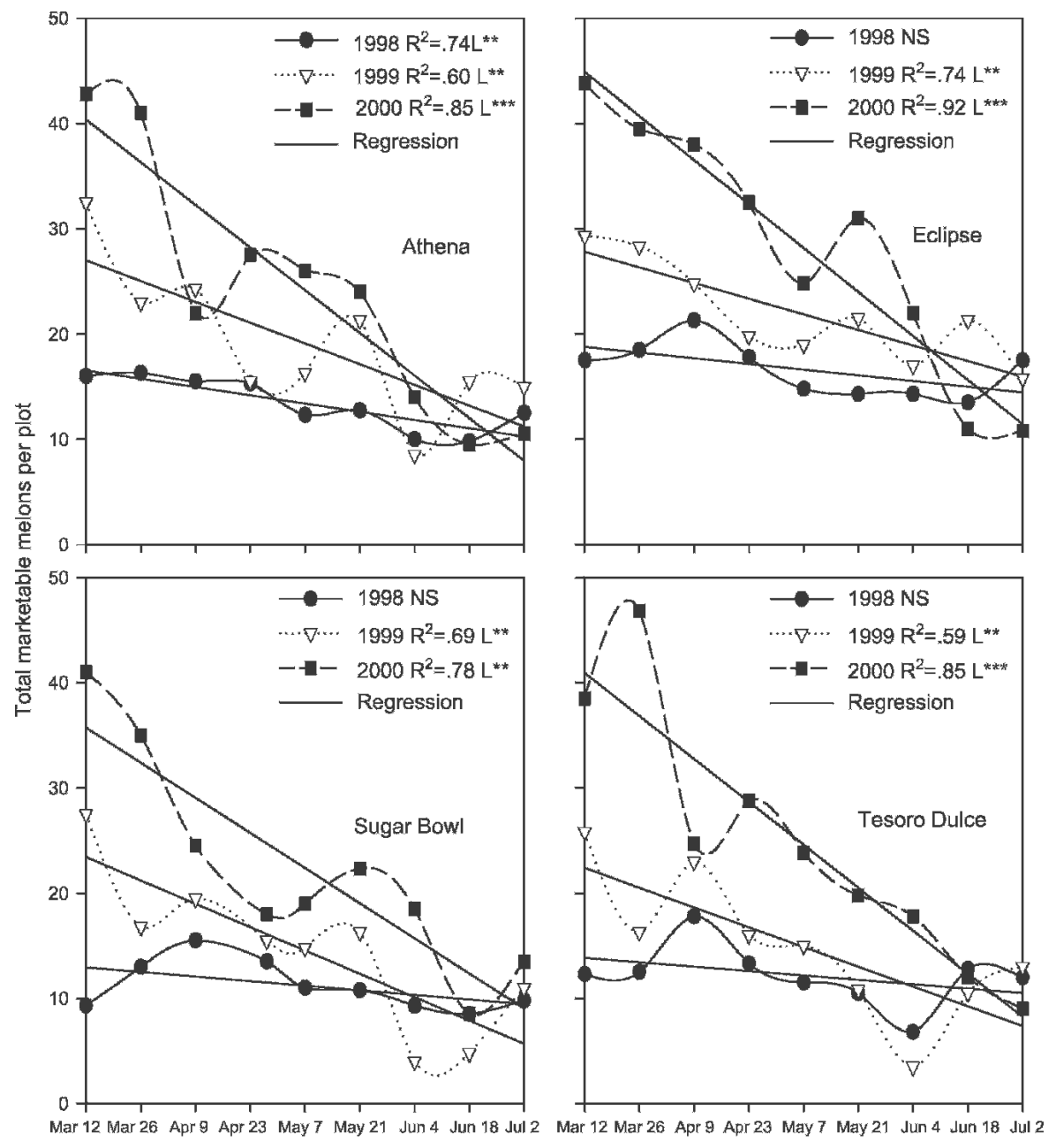

Planting Date

Fig. 3. Interaction of planting date, year, and cultivar on the number of marketable melons per plot. Polynomial regression was performed on all planting date $\times$ cultivar within each year and noted as not significant (NS) or linear (L). $\mathrm{R}^{2}$ and level of regression model significance are given in the legend as: ** and *** significant at the $P=.01$ and 0.001 levels, respectively). The 12 and 26 Feb. planting dates were eliminated as a result of poor stands and no earliness advantage.

and 'Eclipse' produced the greatest numbers of melons per plot from 26 Feb. to 26 Mar. and from 26 Feb. to 9 Apr. planting dates, respectively. Pooling yield data by cultivar overall planting dates indicated that 'Eclipse' was the most productive cultivar followed by 'Athena' with both 'Sugar Bowl' and 'Tesoro Dulce' yielding similarly but lower than 'Athena' and 'Eclipse'. However, on a marketable weight per plot basis, greatest yields occurred in the 12 and 26 Mar., 9 Apr., and 21 May planting dates (Fig. 2F). In comparison with the 12 Mar. planting date, marketable weight per plot for 12 and 26 Feb. planting dates, respectively, decreased $27 \%$ and $8 \%$, probably as a result of fewer melons produced per plot as mentioned previously. Contrasting the marketable weight per plot of the 12 Mar. planting date to all plantings from 9 Apr. and later indicated progressive decreases in yield.

Melon sugar differences. The main effect of planting date accounted for $46 \%$ of the variation with much lesser proportions resulting from cultivar $(11 \%)$ and the interaction of planting date and year (11\%) (Table 1). The greatest sugar content occurred in the $26 \mathrm{Feb}$. through 9 Apr. planting dates and then progressively declined in later planting dates (Fig. 4A). Sugar content in 'Athena', 'Eclipse', and 'Tesoro Dulce' were $\geq 11 \%$ from $12 \mathrm{Feb}$. to 9 Apr. planting dates, but in comparison, 'Sugar Bowl' maintained a sugar content $\geq 9 \%$ but $\leq 11 \%$, but by the 23 Apr. planting date, the sugar levels dropped below 9\%, then decreasing below $8 \%$ in all planting dates after 7 May. Therefore, the last planting date for 'Sugar Bowl' should be 9 Apr. to ensure high-quality melons. Sugar level for 'Tesoro Dulce' fell below $9 \%$ on the 23 Apr. planting date and below $8 \%$ on planting dates $\geq 4$ June, and the last planting date for this cultivar should not be later than 7 May. 'Athena' maintained a greater sugar content than 'Sugar Bowl' and 'Tesoro Dulce' for a longer time period, but after the 18 June planting date, it decreased $<9 \%$ indicating that 4 June was the last possible planting date for 'Athena'. 'Eclipse' was the only cultivar that maintained sugar content above $9 \%$ for 10 of 11 planting dates. Averaged overall planting dates, 'Eclipse' had the greatest sugar content followed by 'Athena', 'Tesoro Dulce', and 'Sugar Bowl'.
Cull yield differences. The majority of variation in number of cull melons per plot was attributed to the main effects of planting date $(15 \%)$, year $(12 \%)$, and their interaction (26\%) (Table 1). Cull yields were lowest in the 12 Feb. planting date, but this is an artifact of stand loss and lower plant populations (Fig. 4B). Averaged over cultivars, cull number per plot were similar from the 26 Feb. to 7 May planting dates but increased from the 4 and 18 June planting dates. Of the total melons produced (cull and marketable) from 12 Feb. to 7 May planting dates, the proportion classified as cull ranged from $10 \%$ to $13 \%$; however, culls increased to $18 \%$, $39 \%, 52 \%$, and $27 \%$ in 21 May, 4 and 18 June, and 2 July planting dates, respectively. The increase in culls during those planting dates was primarily the result of abnormal rainfall and greater disease pressure in 1999 but not 1998 and 2000. Of the four cultivars evaluated, culls (averaged overall planting dates) were greatest for both 'Athena' and 'Sugar Bowl' followed by 'Tesoro Dulce' and 'Eclipse' $(-23 \%$ and $-37 \%$ less than the average of 'Athena' and 'Sugar Bowl', respectively).

\section{Discussion}

Optimal melon yield and quality depends on optimal temperatures for foliage and fruit growth, and pollination, but optimal melon yield did not always coincide with the greatest concentrations of soluble solids (Table 2). Also, cultivars did not yield ideally in the same planting dates; for example, 'Athena' produced the most marketable melons per plot from the 26 Feb. to 26 Mar. planting dates; 'Eclipse' from 26 Feb. to 9 Apr.; 'Tesoro Dulce' from 12 Mar. to 9 Apr.; and 'Sugar Bowl' from 12 to 26 Mar. planting dates. Using February planting dates was not successful because of great stand loss and melon maturity was about the same time as the standard March planting dates. Extending the production season using later planting dates than 15 May was successful, but the number of melons produced decreased linearly with later planting dates. The reduction in productivity of melons in the later planting dates may be the result of several plausible explanations. Baker and Reddy (2001) in Texas reported that greater air temperatures in midsummer may reduce bee activity and pollination and may affect the reproductive development or shortening the duration of the growing season. High temperatures and long days tend to keep cucurbits in the staminate phase, whereas low temperatures and short days speed up development so that the pistillate phase is reached after fewer nodes have developed (Whitaker and Davis, 1962). It is possible that pollen or egg fecundity may have reduced fruit set.

Melon sugar concentrations are a critically important quality characteristic and were greatest in the earliest planting dates with temperatures ranging from $\approx 20$ to $23{ }^{\circ} \mathrm{C}$, but with the warmer planting dates, sugar decreased significantly. Because melons in 

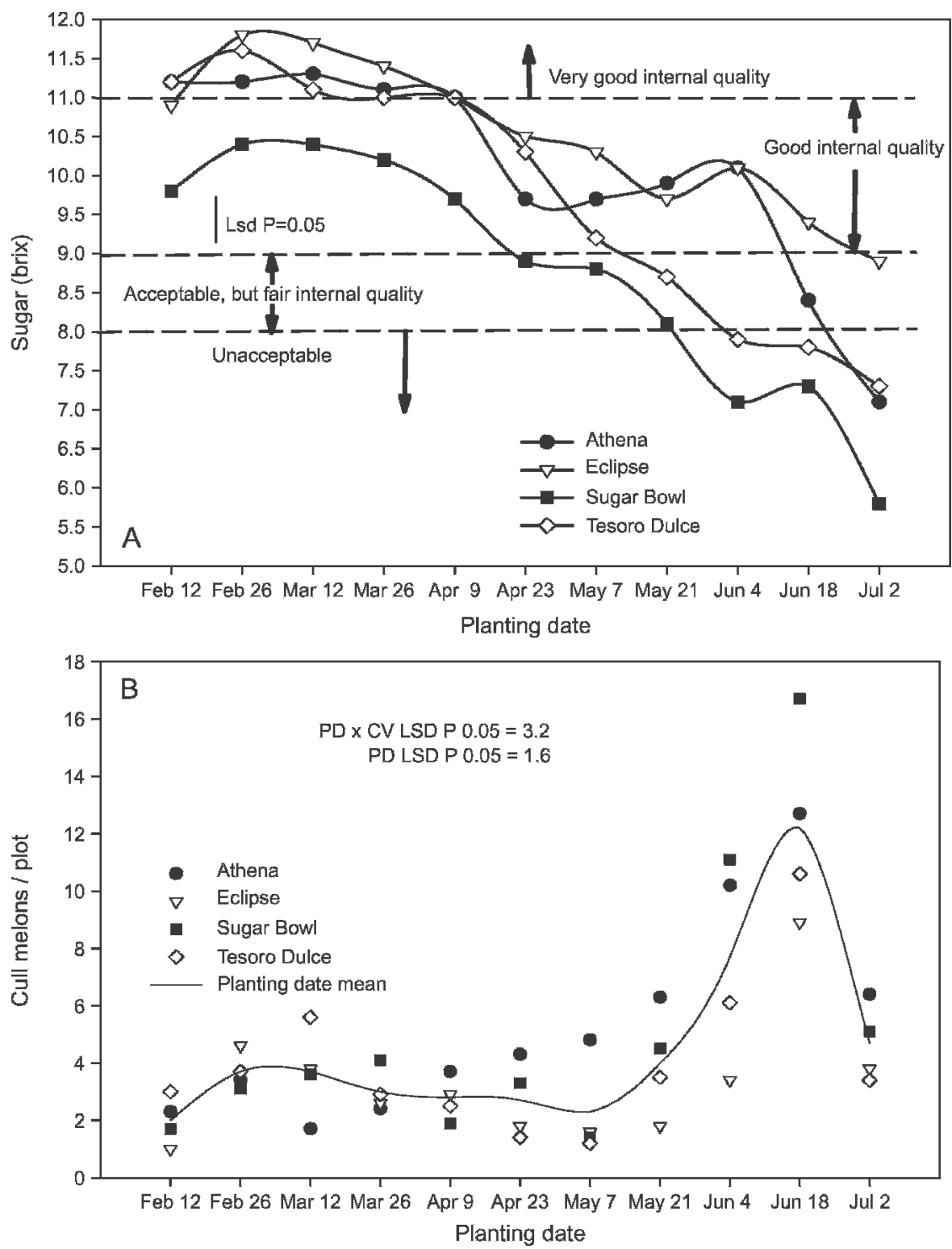

Fig. 4. Influence of planting date from February to July and cultivar on: (A) melon sugar (Brix); and (B) number of cull melons per plot of melons grown from 1998 to 2000 in Charleston, S.C.

later planting dates matured faster in the warmer temperatures, the length of the growing season was reduced and the time to develop sugars may have been reduced. Welles and Buitelaar (1988) found that any factor that shortens the period from flowering to fruit maturity also reduced muskmelon soluble solids. Additionally, Bianco and Pratt (1977) found that a large part of sucrose enters mature muskmelon during the last week before harvest. Apparently, climatic conditions just proceeding harvest are critical to quality, if too warm, may reduce sugar accumulated in the melons. Extension of the production season using later planting dates is useless if sugar levels are expected to be $<8{ }^{\circ}$ Brix. Using planting dates that are likely to produce mostly "fair internal quality" of $<9{ }^{\circ}$ Brix may introduce too much risk of inferior product quality and consumer rejection. Therefore, in our study, we concluded that any planting date that could
Table 2. Summary of significant yield events for four melon cultivars grown on 11 planting dates from 1998 to 2000 .

\begin{tabular}{|c|c|c|c|}
\hline \multirow[b]{2}{*}{ Cultivar $^{\mathrm{z}}$} & \multirow[b]{2}{*}{ Event } & \multicolumn{2}{|c|}{ Planting date ${ }^{\mathrm{y}}$} \\
\hline & & Earliest & Last \\
\hline $\begin{array}{l}\text { AT EC } \\
\text { SB }\end{array}$ & $\begin{array}{l}\text { Greater than } \\
25 \% \text { stand } \\
\text { loss }\end{array}$ & 12 Feb. & $26 \mathrm{Feb}$. \\
\hline TD & “ & 12 Feb. & 9 Apr. \\
\hline AT & $\begin{array}{l}\text { Greatest number } \\
\text { of melons } \\
\text { set per plot }\end{array}$ & 26 Feb. & 26 Mar. \\
\hline $\mathrm{EC}$ & “ & 26 Feb. & 9 Apr. \\
\hline TD & “ & 12 Mar. & 9 Apr. \\
\hline SB & “ & 12 Mar. & 26 Mar. \\
\hline $\begin{array}{l}\text { AT SB } \\
\text { TD }\end{array}$ & $\begin{array}{l}\text { Greatest number } \\
\text { melons per } \\
\text { plant }^{\mathrm{x}}\end{array}$ & $26 \mathrm{Feb}$. & $26 \mathrm{Feb}$. \\
\hline $\mathrm{EC}$ & “ & 12 Feb. & 12 Feb. \\
\hline AT & $\begin{array}{l}\text { Greatest } \\
\text { individual } \\
\text { melon weight } \\
\text { within cultivar }\end{array}$ & 21 May & 18 June \\
\hline EC SB & “ & 7 May & 2 July \\
\hline $\mathrm{TD}$ & “ & 23 Apr. & 4 June \\
\hline AT & $\begin{array}{l}\text { Greatest } \\
\text { marketable } \\
\text { weight per } \\
\text { plot }\end{array}$ & 26 Feb. & 26 Mar. \\
\hline $\mathrm{EC}$ & “ & 21 May & 21 May \\
\hline SB & “ & 12 Mar. & 9 Apr. \\
\hline $\mathrm{TD}$ & “ & 26 Mar. & 26 Mar. \\
\hline $\begin{array}{l}\text { AT EC } \\
\text { SB TD }\end{array}$ & $\begin{array}{l}\text { Greatest } \\
\text { number of culls } \\
\text { per plot }\end{array}$ & 18 June & 18 June \\
\hline $\begin{array}{l}\text { AT } \\
\text { EC TD }\end{array}$ & $\begin{array}{l}\text { Very good } \\
\text { internal quality }\end{array}$ & 12 Feb. & 9 Apr. \\
\hline AT & $\begin{array}{l}\text { Good internal } \\
\text { quality }\end{array}$ & 23 Apr. & 4 June \\
\hline EC & “ & 23 Apr. & 18 June \\
\hline TD & “ & 23 Apr. & 7 May \\
\hline SB & “ & 12 Feb. & 9 Apr. \\
\hline AT & $\begin{array}{l}\text { Fair internal } \\
\text { quality }^{t}\end{array}$ & 18 June & 18 June \\
\hline $\mathrm{EC}$ & “ & 2 July & 2 July \\
\hline TD & “ & 21 May & 21 May \\
\hline SB & “ & 23 Apr. & 21 May \\
\hline AT & $\begin{array}{l}\text { Unacceptable } \\
\text { internal } \\
\text { quality }^{\mathrm{s}}\end{array}$ & 2 July & 2 July \\
\hline $\mathrm{EC}$ & “ & None & \\
\hline TD SB & “ & 4 June & 2 July \\
\hline
\end{tabular}

${ }^{\mathrm{z}} \mathrm{AT}=$ Athena, $\mathrm{EC}=$ Eclipse, $\mathrm{SB}=$ Sugar Bowl, $\mathrm{TD}=$ Tesoro Dulce.

${ }^{y}$ Earliest and last planting date to demonstrate this specific yield event.

${ }^{x}$ During this planting date, individual plants produced at least five marketable melons per plant. ${ }^{\mathrm{w}} 12 \mathrm{Feb}$. planting date ignored because stands were very poor and surviving plants had minor interplant competition. The planting date chosen for this event was selected on the performance of that single cultivar versus planting date.

"Brix $\geq 11.0 \%$.

"Brix $>9.0$ to $<11 \%$.

'Brix $\geq 8.0 \%$ to $9 \%$.

${ }^{\mathrm{s}}$ Brix $<8.0 \%$. 


\section{Literature Cited}

Baker, J.T. and V.R. Reddy. 2001. Temperature effects on phenological development and yield of cantaloupe. Ann. Bot. (Lond.) 87:605-613.

Bianco, V.V. and H.K. Pratt. 1977. Compositional changes in muskmelons during development and in response to ethylene treatment. J. Amer. Soc. Hort. Sci. 102:127-133.

Bruton, B.D., T.K. Hartz, and E.L. Cox. 1985. Vine decline in cantaloupes as influenced by cultivar and planting date. HortScience 20:899-901.

Lee, J., J. Lee, J. Ku, W. Kim, and Y. Om. 1998. Cultivars and planting date for August pro- duction of cantaloupe (Cucumis melo) in alpine area. RDA J. Hort. Sci 40:31-36.

McGlashan, D.H. and W.J. Fielding. 1990. Effects of planting date and spacing on yield of cantaloupe cultivars at Bodles, Jamaica. Proc. Interamerican Soc. Tropical Hort. 34: 71-72.

Nandpuri, K.S. and T. Lai. 1978. Varietal response to date of planting in cantaloupe. Veg. Sci. 5: $8-14$.

Sanders, D. 2005. Vegetable crop guidelines for the southeastern U.S. Helena Chemical Co., Memphis, Tenn.
U.S. Department of Agriculture (USDA). 1967. United States standards for grades of honeydew melons.

U.S. Department of Agriculture (USDA). 1968. United States standards for grades of cantaloupe.

Welles, G.W. and K. Buitelaar. 1988. Factors affecting soluble solids content of cantaloupe (Cucumis melo L.). Netherlands J. Agr. Sci. 36:239-246.

Whitaker, T.W. and G.N. Davis. 1962. Cucurbits, botany, cultivation, and utilization. World Crop Books, Interscience Pub., N.Y. 